\title{
Making the Brand Appealing: Advertising Strategies and Consumers' attitude towards UK Retail Bank Brands
}

\author{
ABSTRACT \\ Purpose \\ The present state of the financial services industry suggests the need for banks to appeal to \\ consumers' emotions with the aim of improving their reputation; this study explores how UK \\ banks are using emotional appeals in their advertisements and how this shapes consumers' \\ attitudes towards their brands.
}

\section{Design/methodology/approach}

Qualitative and quantitative data collection and analysis in a two-stage study - Study 1 analysed the content of 1,274 UK bank advertisements to understand how the banks convey emotional appeals, while Study 2 elicited consumers' perceptions of these advertising appeals and how they influenced their attitudes through semi-structured interview with 33 UK retail bank customers in London and Luton.

\section{Findings}

UK banks are using emotional appeals in their marketing communication strategies. The qualitative findings highlight the bi-dimensional nature of feelings towards the advertisements and how this relates to the brand. There is a lacklustre attitude towards the brands; there was no sense of pride in associating with any bank, even with though there are possibilities of switching; and consumers feel there is no better offer elsewhere as all banks are the same.

\section{Practical implications}

Bank brands should present distinct values about their services to the target audience, endeavour to build relationships with existing customers and reward loyalty. Importantly, financial brands need to engage in and highlight charitable activities and any corporate social responsibility as this can help to improve consumers' attitudes as they often consider bank brands greedy and selfish.

\section{Originality/value}

Qualitative research methodology was adopted to better understand consumers' attitudes towards UK retail bank brands.

Keywords: UK, Banks, Brand communication, Emotional branding, Attitude to brand, Attitude to advertisement 


\section{$1 \quad$ Introduction}

The unprecedented turbulence and uncertainty experienced in global economic and financial markets due to the credit crunch has had a damaging impact on consumer confidence (McKechnie, 2011). The global financial crisis of 2007-2008 has eroded the trust and credibility attached to UK banks as safe places to deposit savings (MarketLine, 2014). UK banks were badly affected by the crisis, resulting in major banks needing government bailouts. Heinonen (2014) notes that in the wake of the crisis, the banking sector have been transformed, with new regulations and competition for customers and profits. Unprecedented turmoil has been witnessed in the European banking market as it underwent a period of massive uncertainty and change during the financial crisis (Saiz and Pilorge, 2010; Jarvinen, 2014).

Banks' engagement in various activities has also put their customers at risk. Denning (2013) notes that bad profits were achieved through practices by the banks that were shady but not strictly illegal. These practices included the price fixing of the London Interbank Offered Rates, abuses in foreclosure, money laundering for drug dealers and terrorists, assisting tax evasion and misleading clients with worthless securities, all of which have further eroded consumers' trust in the banks. Barber (2014, p.243) notes: "These days, bankers are widely viewed as greedy, self-serving, amoral or actually dangerous. Estate agents, even journalists, are held in higher regard".

Moreover, Gritten (2011) notes that many of the bank customers feel let down by a system and by institutions that had promised, and often claimed to guarantee, to protect them and their assets, suggesting the need for financial services institutions to build constructive dialogue and long-term, meaningful relationships with their customers once again. 
The present state of financial services has suggested the need to appeal to consumers' emotions with the aim of improving their reputation. To this end, an appealing advertising strategy could work in this case: as Jones (1990) suggests, advertising aims to increase consumers' knowledge and change their perceptions of different products and services. Furthermore, the competition within the industry could suggest the need to adopt an emotionally appealing advertising strategy as emotions are known to play a role in building long-lasting brand preferences (Kenning and Plassmann, 2005). The current situation also highlights the need for advertisers to come up with a distinctive advertising strategy to set them apart from their competitors, as some studies have demonstrated that emotional differentiation in a competitive market can be achieved by using emotional advertising strategies (Hartmann et al., 2005; Ghodeswar, 2008; Salander, 2010).

The aim of this study is to expand on previous studies on consumers' attitudes towards the UK banking industry and enhance the understanding of the use of emotional appeals in financial services marketing communications. This is achieved by gathering and analysing qualitative and quantitative data in a two-stage study. Study 1 explored UK banks' advertisements to understand how they convey emotional appeals, while Study 2 elicited consumers' perceptions of these advertising appeals and how they influence their attitudes towards UK retail bank brands.

The study is conceptualised theoretically based on the idea that a positive attitude towards an advertisement, achieved by embedding emotionally appealing features such as images and copy, will in turn lead to a positive attitude towards the brand (Mitchell and Olson, 1981; Lutz et al., 1983; MacKenzie and Lutz, 1983) and social judgement theory. The creative strategies in UK banks' print advertisements are explored through content analysis, while the anticipated positive attitude towards their brands is elicited though semi-structured 
interviews, which allow the participants to report their attitudes towards UK bank brands verbally.

Even though previous studies have explored attitudes towards bank brands shortly after the financial crisis (Bennett and Kottasz, 2012; Johnson and Peterson, 2014), we adopted a research methodology which seeks to understand this still unfolding phenomenon, as even after the crisis, the ripple effect is still being observed. Following a similar line of thought to Cooper (1999) and O'Cass (2004), we acknowledge that brands often meet consumers' rational, emotional, social and cultural needs, and these complexities cannot be measured simply, rather by adopting a more in-depth approach to gain a better understanding.

Spears and Singh (2004) acknowledge that even though there are bewildering arrays of choices in measuring attitude to brands, there are no standard, psychometrically validated scales, as the overwhelming majority of studies measuring this construct have used different sets of items. Batra and Ray (1986) used a four-item scale (useful/useless, important/unimportant, pleasant/unpleasant, and nice/awful), while MacKenzie, Lutz and Belch (1986) used a three-item, seven-point scale (favourable/unfavourable, good/bad, and wise/foolish). This difficulty in adopting a generally acceptable scale offers justification for a qualitative approach, engaging with the customers to gain a better understanding of this construct.

This study will provide an important theoretical contribution to the study of financial services brands, especially in the UK context, and managers will be able to consider appropriately the implications of their marketing strategies in reconnecting with their customers, enhancing their brand image and, most importantly, rebuilding consumer trust in their brands. The subsequent sections provide the theoretical background, research designs and philosophical stances for each of the studies, followed by a discussion which bridges the gap between both 
studies and the conclusion, which highlights the implications, the limitations of the study and suggestions for further research.

\section{$2 \quad$ Literature Review}

\subsection{Attitude towards UK retail bank brands}

With the global financial crisis of 2007-2008, the trust and credibility attached to financial services providers has been eroded. Consumers appear to not trust the banks. The big banks engaged in various activities that put their customers at a higher risk. There were technical issues that affected customers' access to their money, widespread charges of market manipulation, and a loan price-fixing scandal. Consumers' perception of the bank brands in the wake of these issues is questionable, and the individual's internal evaluation of the brand is a measure of their attitude towards the brand (Mitchell and Olson, 1981).

Evans (2012) mentions that there was a knock-on effect on the banks' reputations and customers' diminishing trust in banks. Citing the Edelman Global Trust Survey of 2013, Denning (2013) notes that despite years of intense regulatory effort, banking is still the leasttrusted sector in the whole global economy. Denning (2013) suggests that the banks need to improve their reputation, for example, through public relations and marketing communications, or else they risk losing their customers to other competitors, especially the new entrant banks. Unlike the bigger brands, the new banks, for example, Metro, Virgin Money, Tesco and Marks \& Spencers, can build upon their existing corporate reputations; the goodwill attached to their brands can attract consumers.

Moreover, with the ever increasing need to offer a unique product in a market where most of the products are the same, the financial industry is becoming more competitive in competing for consumers. Although the big four banks in the UK do have an edge, over the new entrants 
and with the regulations, it is important for financial services providers to create awareness about what sets them apart and reach out to prospective customers, providing the information consumers need to make financial choices.

This has given rise to the need for banks to communicate messages about their products and innovations, for instance, the possibility of switching between banks within seven working days; the ability to send money without using the branch; online and mobile bank transfers; and the various technological advancements available to make banking easier, such as mobile applications on smartphones and subscribing to text messages to warn consumers when they have reached the set limits of the account. Consumers will not find out about all of these features unless they are advertised and presented in an appealing manner.

Furthermore, Clow et al. (2005) note that a consumer's intention to purchase must be driven by a positive attitude towards the advertisement as well as the brand. They state that if consumers cannot relate to the brand, they might not patronise it, even when the advertisement gets their attention. The authors were able to identify the need for an advertisement to appeal to viewers' emotions for it to be effective, describing it as an affective creative message strategy whereby the advertisement can appeal directly to viewers' emotions. They conclude that visuals can be used to create positive feelings towards the advertisement and that copy can be used to create a positive attitude towards the brand.

\subsection{Strategic execution of emotional appeal}

As stated earlier, it is anticipated that banks will need to improve their reputation through public relations and marketing communications. Emotional appeals in advertising strategies have been known to help in strengthening brands as they add another distinction to the brand (Panda et al., 2013), and with the need to improve brand reputations, this could be deemed suitable for the UK retail bank brands. Holbrook and O'Shaughnessy (1984, p.47) argue that 
"emotional, subjective impressions of intangible aspects of the product" are emphasised in emotionally appealing advertisements. Baines et al. (2008) suggest that they are based upon consumers' feelings and emotions. Emotional appeals presented in advertisements are directed mainly to psychological aspects of consumers' needs and the feelings associated with the product (Bovée and Arens, 2000). According to Franke et al. (1999), emotional appeals attempt to stir up either negative or positive emotions, leading to purchase motivation.

Heath et al. (2009, p.2) describe emotive content as "anything in advertising that is capable of stimulating the feelings of the viewer" while acknowledging that the creative approach in the design and development of marketing communication materials is crucial in arousing emotions in individuals viewing it. Heath et al. (2006, 2009) discuss the benefits of emotionally appealing advertisements in building brand relationships, especially the creative choice of employing emotional content in advertisements, suggesting that they are more successful than rationally appealing messages in generating brand favouritism. Brader (2006, p.68) concludes that an emotional appeal is "any communication that is intended to elicit an emotional response from some or all who receive it".

Advertising appeals provide the basis for attracting the attention or interest of consumers and/or influencing their feelings towards a product or service (Kinnear et al., 1995). Appeals are incorporated into advertisements in the form of text and images to attract viewers' attention and provide information about the brand. Mitchell (1986) observes that advertisements containing visual elements are designed to prompt an emotional feeling. Visual elements presented in the form of images and text in an advertisement can affect attitudes towards brands, as individuals form their perceptions of the brands based on the visual information that has been presented (Mitchell and Olson, 1981; Mitchell, 1986). 
Clow et al. (2005) note that choosing an image that is memorable and that matches the written copy of the advertisement can lead to a positive attitude towards the advertisement, which in turn directs attention to the brand and increases intention to purchase. Kisielius (1982) states that the addition of an image to an advertisement could create either a positive or a negative brand attitude, depending on the message transmitted by the image. Moreover, Adir et al. (2012) note that images attract consumers to read through an advertisement; they suggest that an emotional image requires simple copy and vice versa. This is consistent with the study by Unnava and Burnkrant (1991), which demonstrates that advertisements with text and images to demonstrate a product's attributes are more effective than those using just images.

The textual component of an advertisement, for example, headlines, taglines and copy, can also be used to encourage a positive attitude towards the brand. Wilmshurst and Mackay (2010) and Decrop (2007) suggest that such text has to be clear, uncomplicated, direct, appropriately expressed and relevant to the target audience, and must be connected with the other components of the advertisement, while Bovée and Arens (2000) conclude that the verbal components of an advertisement close the deal. Decrop (2007) highlights that the textual components of an advertisement must provide customers with information regarding the advertised product or brand, emphasising its benefits and creating an intention to buy.

The ability to hold together these seemingly inconsistent components of a print advertisement, making a new function, is considered creativity (O'Guinn et al., 2006). Yu (2007) describes creativity in print advertisements as the combination of visuals and textual headings in a well laid-out manner which affects how it will be perceived and read by the target audience. Decrop (2007) found that images and text in advertisements are the prevailing elements; this was corroborated by $\mathrm{Yu}$ (2007), who argues that visuals and 
headlines are the most important components in print advertisements and that they interact in different ways to present creative messages about a brand.

\subsection{Attitude towards brand and advertisement construct}

The theoretical framework for this research highlights the brands' efforts in appealing to consumers through their advertisements; this is considered in the context of the attitude advertisement construct, highlighting the possibilities of a significant correlation between favourable attitudes towards advertising and a favourable attitude towards the brand. This construct was first explored by Lutz et al. (1983), and it has been used in a considerable number of empirical studies (e.g. Batra and Ray, 1986; MacKenzie et al., 1986; MacKenzie and Lutz, 1989) to understand consumer behaviour with regard to advertisements.

Attitude towards advertisements is defined as a "predisposition to respond in a favourable or unfavourable manner to a particular advertising stimulus during a particular exposure occasion" (MacKenzie and Lutz, 1989, p.49). This correlates with Kotler's (2000) description of attitude as a favourable or unfavourable assessment, opinion, emotional feelings, and action towards an idea, in this case financial services brands.

Spears and Singh (2004, p.55) conceptualise attitude towards the brand as "a relatively enduring, unidimensional summary evaluation of the brand that presumably energizes behaviour". The fact that customers have in one way or another had an encounter with the bank brands will definitely influence their attitude, as there is "imputation of some degree of goodness or badness" (Eagly and Chaiken, 1993, p.3).

In achieving this attitude, the creative design of the advertisement is considered paramount. Moving on from previous studies on the mechanical and executional aspects of the advertisements which enhances attitudes towards advertisements (Batra and Ray, 1986; Belch and Belch, 2015), In line with Mogaji (2016), we considered emotional appeals embedded in 
the advertisements as a creative choice to arouse a positive attitude towards the advertisements.

Understanding these embedded emotional appeals is also considered within the social judgement theory context. This theory was developed by Muzafer and Hovland (1961) to understand how individuals weigh up options based on their initial attitude; it suggests that an individual exposed to advertisements views them in the light of what they already know or feel and a subjective standard is developed when making judgements about the embedded meaning (Solomon et al., 2006).

A crucial aspect of the theory is the idea that there are differences in what individuals considered acceptable or unacceptable and this forms the "latitudes of acceptance and rejection around an attitude standard. Ideas that fall within a latitude will be favourably received, while those falling outside this zone will not" (Solomon et al., 2006, p.176). With regard to UK retail bank brands, which is the focus of this study, we anticipate exploring the attitude towards bank advertisements, if they have been favourably received or not and how they enhance attitude towards the brand.

As Mogaji et al. (2016) note, UK banks are now making efforts to rebuild their reputation by creating emotionally appealing advertisements, incorporating values that customers can relate to and, in turn, will affect their perceptions about these brands. It is possible that creating a positive attitude towards the industry is considered paramount following the global financial crisis, as various media reports have suggested that the British public's evaluation of the calibre of the banking industry has declined, with both the integrity and the competence of the banking industry being questioned (Wray, 2008; Crowley, 2010).

Advertising appeals have been found to affect both attention to the advertisement and attitude towards the brand, which can be either positive or negative (Kinnear et al., 1995). This study 
is approached from two perspectives, firstly, from the brand point of view - the emotional appeals they are sending out through their advertisements to enhance a positive attitude - and secondly from the customer perspective - to understand how these emotional appeals influence their attitudes towards the advertisements and also towards bank brands. It is possible that if they like the advertisement as it is emotionally appealing, this favourable attitude can be transferred to the bank brands.

Holbrook (1987) notes that consumers are more likely to respond to appeals that they perceive to be relevant and important to them, as these appeals are influenced by the values that are prevalent in their society. The UK retail bank brands' effort in appealing to consumers through their advertisements and how it enhances the attitude towards their brand, if at all, is the focus of this study. Though Shimp (1993, p.11) notes that advertisers aim to appeal to the "customer's functional, symbolic and experiential needs through effective communications", the individual preferences in decoding the emotional appeals presented in the advertisements cannot be ignored as this inadvertently influences their attitude towards the brands.

\section{Research Questions}

To achieve the aims of this study, the following research questions are considered in the two studies, conducting content analysis in Study 1 to explore the emotional appeals in the advertisements and using semi-structured interviews in Study 2 to understand how they influence attitudes towards the brand:

$R Q$ 1: How are UK banks presenting emotional appeals in their advertisements?

$R Q$ 2: How are these presented emotional appeals influencing consumers' attitudes towards the brand? 


\subsection{Research design and methods}

Content analysis is arguably one of the most suitable methods for analysing advertisements used by various other researchers (Belch and Belch, 2013; Mogaji, 2015). Krippendorf (1980) describes it as a research technique for making replicable and valid inferences from the data regarding their contexts.

Emotionally appealing advertisements were determined based on the visuals and the textual content of the advertisements. For example, the portrayal of a daughter relaxing in the loving arms of her father was classified as 'affiliation', 'family' and 'love'. The textual presentation of advertising messages was in the main headline and copy of the advertisement. The headline of the advertisement is the main and prominent text of the advertisement; in most cases, it is bold to grab the attention of the reader and it can also relate to the images used.

The ontological stance surrounding the content analysis is that there is one reality, it is out there, and it can be discovered with the scientific process. For the purpose of this study, that means the appeals used by banks exist and are independent of any social actor as they can be identified based on the coding framework that has been developed. As researchers, findings from the content analysis are beyond our reach and the data cannot be controlled. On this note, it was safe to adopt an objectivist ontological position and base this research within the positivist paradigm.

The scientific process of the content analysis, using the developed coding framework, suggested that a positivist philosophical stance could be adopted for this research. It is expected that coders anywhere in the country can identify the banks, the kind of financial products and the advertisement sizes, as indicated in the coding framework. The presence of coders selecting the advertising appeals they could identify from the advertisements suggests 
that there are differences between humans as social actors, as suggested by Saunders et al. (2015).

In developing an applicable set of appeals for this study, four lists of advertising appeals were identified and considered for a comprehensive list of appeals for the content analysis. The list includes Pollay’s (1983) emotional advertising appeals, Moriarty’s (1991) emotional appeal list, specifically, as it contains negative emotional appeals, Fowles's (1994) 15 advertising appeals and Hetsroni's (2000) list. This led to an applicable typology of 15 appeals for the present study, which is presented in Appendix 1.

\subsubsection{Sampling}

All UK bank advertisements bigger than a quarter of a page obtained from nine national newspapers in the UK collected between April 2013 and March 2014 were analysed. The criteria used to select the newspapers were category, popularity (circulation figures) and readership demographics (range and variety of the audience). The newspapers were divided into the frequently used categories of 'quality', 'mid-market' and 'popular' papers on the basis of their readership profile, style of presentation, and level of reporting and commentary.

The final newspaper sample for this content analysis includes three newspapers from each of these three frequently used categories - 'quality' newspapers (Guardian, Daily Telegraph and Times), 'mid-market' newspapers (Daily Express, Daily Mail and Metro) and 'tabloid/popular' newspapers (Sun, Daily Mirror and Daily Star) (Mogaji, 2015). The readership characteristics of the selected newspapers show considerable differences in the readership profiles in terms of their age range as well as socioeconomic class differences.

Repeated instances of the advertisements in the same size, and in the same newspapers, were excluded, and a sample of 1,274 print advertisements was selected for the analysis. 


\subsubsection{Coding}

To determine the emotional appeals presented in the banks' advertisements in the collected sample, an analysis of the visual (images, colours and graphics) and verbal (headlines and copy) elements of advertising messages needed to be performed. In the first place, advertising messages were considered to be emotionally appealing if they contained any of the listed 15 appeals. Emotionally appealing advertisements were determined based on the appeals incorporated into the advertisements through the visuals and the textual content of the advertisements.

Other creative features of the emotionally appealing advertisements, such as number of words, colours and images used in the advertisements, were also considered during the analysis. Text length in the advertisements was coded as either '50 words or less' or 'more than 50 words', as Starch (1966) found that advertisements with 50 words or less were more than twice as likely to be read than those with more than 50 words. Colours were coded as 'full colours', 'two colours' and 'black and white'. Images were coded as cartoon, celebrities, cats and/or dogs, customers and colleagues. Furthermore, the banks and the products (high and low involvement financial products) were included in the coding framework.

A web application for the content analysis was developed to help in the recording of the content analysis of the advertisements. The web application replicated the paper content analysis but included radio buttons and dropdown menus to allow selections within the categories. This was to ensure that the coding sheet was user-friendly, as it resembles an online form that most Internet users are used to. Data was extracted from the backend database, exported into Microsoft Excel 2013 (v15.0), and then used for further analysis in SPSS Version 23. 
Two individuals coded all the advertisements independently of each other and were not involved in the research or familiar with the design of the study or its purposes. They received eight hours of training, which started with an explanation of the content analysis method and the processes involved. They were given the code books and meetings were scheduled regularly where the coding team reviewed each code and definition in the code book to ensure they were being used consistently.

\subsubsection{Validity}

To ensure validity, a pilot test was conducted to test the coding framework. Useful comments were obtained to develop the coding sheet further and include more detailed information in the coding book, which included clarifications about the bank groups (for instance, though First Direct is a subsidiary of HSBC, it is classified as a 'new entrant' while the parent company is an 'established brand'), and better descriptions of the emotional appeals (with examples) were provided.

Three hundred advertisements were randomly selected to test the intercoder reliability between the two coders, each coder coded the advertisement and their findings were compared. An intercoder reliability check was assessed using both Cohen's kappa and Krippendorff's alpha level of agreement, which ranged from 0.993 to 1.00 . Neuendorf (2002), who reviewed rules of thumb set out by several methodologists, concluded that coefficients of 0.90 or greater would be acceptable to all.. After initial coding, the differences were discussed and resolved collectively with the authors, and the adjusted scores were analysed. None of the authors were involved in the final coding process unless needed to settle a disagreement about identifying the codes. Finally, the independent coders were British, born and raised in Britain with an understanding of the cultural values within the country. 


\subsection{Results}

From the sample of 1,274 print advertisements, NatWest Bank had the highest number of distinct advertisement for the analysis (205, 16.1 percent) while Allied Irish Bank had the least number of advertisement $(8,0.6$ percent). The distribution in the advertisements across different bank groups was also noted. With a frequency of 938 advertisements (73.6 percent), the High Street banks like Lloyds, Barclays and HSBC had the highest number of advertisements, while the non-High Street banks like First Direct, Sainsbury and Post Office had 336 advertisements (26.4 percent). It appeared that the non-High Street banks may not be using the newspapers to reach out to prospective customers. The high number of High Street banks can also be suggested as a cause for this difference, as well as their larger marketing budgets. For example, M\&S Bank was just starting with current accounts, so they did not have as many advertisements. Also, most of the advertisements for Sainsbury were for loans, and not current accounts like the more established brands.

Advertisements that do not contain any of the 15 emotional appeals, which in most cases are referred to as rationally appealing advertisements, were not considered for the rest of the analysis. In addition, Mogaji (2016b) proposed that "rational appeals" is not the exact opposite of "emotional appeals" in advertisements; some advertisements may be predominantly emotionally appealing and yet still contain some rationally appealing messages. From the content analysis, emotional appeals were present in 832 (of 1,274) advertisements (64.6 percent).

The dominant appeal was "relief and relaxation" (554 advertisements, 66.5 percent). It was followed by "excitement" (411 advertisements, 49.3 percent), "secure” (278 advertisements, 33.4 percent), and "adventure" (265 advertisements, 31.8 percent). "Sorrow" (6 advertisements, 0.7 percent) and "sex" ( 4 advertisements, 0.4 percent) were the least used appeals in this sample. 
Images used in advertisements are considered basic graphic elements to incorporate in appeals designed to arouse consumers' emotions. Visuals in the most prominent position within the advertisements were considered in the analysis. The images used in these advertisements were coded as "Cartoon, Animals" (cats and/or dogs), "Celebrities", "Children and Parent", "Colleagues", "Couples" and "Customers". Of the 1,274 advertisements, 633 (49.7 percent) did not have any visual or illustration, which is almost half of the entire sample. Regarding the images of models used in the advertisements, 297 (23.3 percent) featured images of customers; this excludes images that were coded as that of colleagues (seen in uniform with name badges), couples, or children with their parents. Cartoons and other illustrations featured in 118 of the advertisements ( 9.3 percent). This was most often used in the Lloyds TSB Bank advertisements.

Images of colleagues were used in 50 advertisements (3.9 percent). Halifax and NatWest banks featured some of their staff in their marketing communications. Animals, in particular cats and dogs, were used in 22 (1.7 percent) of the advertisements. Santander Bank used the presence of celebrities in their advertisements to present emotional appeals. These are individuals whose status within the country are easily recognised. Jessica Ennis-Hill, Jenson Button, and Rory McIlroy with some of the bank's customers were used prominently in the bank's print media. Santander is the only bank that used celebrities for their advertisement campaign in the sample.

It was also observed that Halifax personalised some of their advertisement models. The names of models were incorporated within the copy and whenever photographs were used. In addition, staff members were sometimes grouped together to form alphabet letters in Halifax advertisements. As a part of the "visualisation of services" advertising strategy, this seems to be a good idea, but it would have been better if the staff could be identified (in twos or 
threes), because without a closer look, it might not be easy to recognise them as staff members.

\section{$5 \quad$ Study 2: Semi-structured interview}

\subsection{Research design and methods}

To understand consumers' perceptions and attitudes towards these emotionally appealing advertisements, we based our qualitative study on semi-structured interviews, as this is an effective method to explore respondents' feelings and perceptions (Crouch and McKenzie, 2006).

Using semi-structured interviews to collect data suggests that there are multiple realities out there which are socially constructed based on individuals' background and social class. This correlates with the explanation provided by Bryman and Bell (2015), which is that social actors which often, provide insights into phenomena. These perceptions of advertisements are not produced and set only by social interaction, but rather they change continually. Unlike the content analysis in Study 1, the perceptions of advertisements may not be the same when research is carried out in another part of the country. Since it is an interaction which is not constant and can change based on these conditions, the ontological position for this part of the research is constructivism.

Furthermore, the participants' perceptions with regard to the advertisements solicited through interviews could vary. This is not a scientific process, but an interaction with humans with different experiences and exposures. Saunders et al. (2015) argue that interpretivism believes in the need for researchers to acknowledge the differences between humans as research subjects. Considering these suggestions, an interpretivist epistemological stance has been adopted to conduct this study. Saunders et al. (2015) also advise that it is crucial to adopt an 
emphatic stance by engaging with participants and constructing perceptions about emotional advertisements of UK banks from their own point of view.

Using a semi-structured interviewing method, the discussion was guided from an introduction to advertising and the role it plays in decision-making. Then, using varying topics, participants were asked about their understanding of advertising, asked them for examples of any advertisements they could remember, and asked them about the role of advertising in decision-making. Six advertisements from different banks which were chosen systematically from the content analysis in Study 1 were then shown to the participants to elicit further details and gain a better understanding of emotions in financial services advertisements.

\subsubsection{Sampling}

The study was conducted in London and Luton between April 2015 and June 2015. Efforts were made to reach a diverse range of participants, and leaflets were sent out to various religious, youth and community centres and morning coffee centres. Electronic copies of the leaflet were also shared on social media networks to attract a demographic variety of participants. A telephone number and email address were provided as contact details. In all, 57 participants contacted the researcher through various means. Of that original number, 33 attended the semi-structured interviews. The time constraints, location and technical nature of the semi-structured interviews, along with the homogeneous sampling techniques, prevented some of the contacts from participating.

Seventeen females (51 percent) and 16 males (49 percent) took part in the semi-structured interviews. The participants' ages ranged from 18 to 72 years. The majority of the participants were of the white ethnic group (54.6 percent). This was followed by Africans, which includes Black Caribbean and Black African (24.2 percent), and Asians, which includes Asian/Asian-British, Indian and Pakistani (21.2 percent). Twenty-one (63.6 percent) 
of the participants were employed, while two had retired, two were self-employed, and the remainder were students, including postgraduate students. Thirteen (39.3 percent) of the participants had a minimum of a bachelor's degree, while one had a $\mathrm{PhD}$; two participants had never attended university.

Measures were taken to ensure that informed consent was given for participation. Prior to the interviews, an information sheet giving a clear idea of the focus of the research and a consent form were sent to participants via email and, in some cases, through the post for those who were not able to access the Internet. The participants were notified that the interview would be audio recorded and were reminded that the information collected would be kept confidential. They were assured that the information would be disguised so that it would not be possible to identify them.

\subsubsection{Data analysis}

The collected data was analysed using a model developed by Strauss and Corbin (1990) known as grounded theory. The extracted comments were coded following a three-part process that is integral to developing a grounded theory: (1) open coding - breaking down, comparing, conceptualising and categorising data; (2) axial coding - reassembling data into groupings or families; and (3) selective coding - developing core themes and relating them to one central concept, i.e. attitude towards UK bank brands through exposure to advertisements (Strauss and Corbin, 1994; 1998; Mogaji et al., 2016).

The three main themes that emerged from the analysis illustrate how creative features in the advertisements prompt participants to develop an attitude towards the brand, highlighting factors that influence these attitudes and how the attitudes towards the bank brands are expressed. 


\subsubsection{Validity and reliability}

Considerable efforts were made to ensure the validity and reliability of this study, one of which was ensuring that participants were given opportunities to stop the interview and would not need to provide any reason for doing so. This was to prevent participants feeling obliged to take part, and it was emphasised that it was entirely their decision to participate. This ensured that those who were genuinely willing to take part and prepared to offer data freely were interviewed.

Each transcribed interview was sent back to the participant to check that it had recorded accurately their thoughts and perceptions about the advertisements shown. Merriam and Tisdell (2015) describe this as respondent validation. It is considered the single most important provision that can be made to bolster a study's credibility (Lincoln and Guba, 1985). As suggested by Shenton (2004), the emphasis is on whether the participants consider that their words match what they intended.

In addition, detailed account of the methods, procedures and decision points in carrying out this study was documented in the form of an audit trail, as advised by Shenton (2004). The assurance of analytic rigour to ensure that data was not used selectively and that the researcher's own position did not overpower the participants' voices can be evidenced from the audit trail.

\subsection{Results}

This section provides a thematic analysis of findings from the semi-structured qualitative interviews exploring consumers' attitudes towards UK retail bank brands. The content analysis of the advertisements presented in Study 1 indicates that UK banks are using emotional appeals in their advertisements. These are considered creative decisions in order to appeal to customers' emotions and enhance the brand image. 
Participants were shown the six advertisements in a booklet, and a verbal (semi-structured interview) self-reporting method was used as the medium to explore their attitudes towards the brands. Three keys themes that emerged from the thematic analysis highlight how consumers form their attitudes towards the brands.

Consumers were exposed to the advertisements, and the creative features prompted their attitudes towards the brands. Following that, these attitudes were influenced by individual perceptions, and finally, their attitudes towards the brands were expressed verbally. These verbal self-reports are presented as selected verbatim extracts from the interview transcripts, although minor changes have been made to enhance readability. An overview of each theme developed in the template analysis is provided as well, followed by a presentation of the main points, supported by extracts from participants' quotes.

\subsubsection{Prompting the attitude}

Participants acknowledged the creative elements in the advertisements, and this initiated the process of expressing an attitude towards the bank brands. They identified the embedded messages in the images, colours and general design of the advertisements as they engaged with the advertisements. The assurance of relief and excitement presented by the banks in their advertisements was acknowledged by the participants, and the embedded meanings of security were transferred through the images and the copy of the advertisements.

Whoa, they are actually touching the emotions, I am feeling happy, they are actually touching the sentiments, it's a good advert and I like it. I like the picture, the background and the joy on the face of the child; I can see the life in it. Someone is caring for me, I don't have worries. (SW, Female, 24)

Young girl running through the sand, probably not a care in the world, running over a sand castle, looks lovely, it's an ideal picture of childhood, I suppose she is very happy and I think perhaps, this is what Nationwide are trying to say, banking shouldn't be stressful, it should be carefree and easy (JMa, Male, 31)

The message from the images show that you can trust the bank, so I don't think I should read the text, what this is telling you is trust, it's love, between mother and 
daughter, so it says a lot, the design is to get this picture to the audience and that's why it's not worded, the message is the image, with covers more than half, this thing now is just trust. (JS, Male, 35)

One of the advertisements by TSB Bank informed the readers boldly in a blue font that they have been in existence for 200 years. Participants recognised these messages of security, and this influenced their attitudes positively towards the advertisement and the brand, as they were able to relate to the guarantees of security from the advertisement.

The only talking about security is the one talking about being there for 200 years, so you think - this bank can rely secures me for years, all things being equal. (AW, Male, 66)

Seems straight to the point, celebrating their old tradition, they have been in existence for years and meaning you can trust them and be rest assured that your money is safe. (MR, Female, 56)

Welcome to your new bank, its local, it's part of you, that one thing I like about TSB, this advert is telling the reader that ok, the bank has been around for 200 years, there is guarantee, its long years of existence is a guarantee of quality. (JS, Male, 35)

In building trust in their brands, the banks used images embedded with an associated meanings of love, security and companionship, such as in a family. Participants' emotions were aroused through these images, and a positive attitude towards the advertisements was presented. An example was from NatWest where there was a mother hugging her daughter, and a Nationwide advertisement featuring a young girl apparently having a good time at the seaside; participants felt they would be in good company and looked forward to being treated well as part of the banks' family.

The NatWest advert is nice, looking homely and welcoming. You feel you are in the good company of the bank, with the mum and daughter, it shows a bit of love you will expect from the bank. (MR, Female, 56)

This is more like it, a sense of belonging, cosy in the arm of those we love-mother and daughter, this is beautiful. You expect the Banks to treat you with love and care but the way they are treating themselves, you doubt if they have your interest at heart. (YU, Female, 47) 


\subsubsection{Shaping the attitude}

After exposure to the advertisements, participants often took their time to explore the creative features of the advertisements, perhaps filtering it through their individual differences and experiences. It is acknowledged that there are many reasons and factors that can influence an attitude towards advertisements; however, specifically, this study revealed three keys themes which influenced these attitudes subtly.

Individuals with strong political views and ideologies about banks are more likely to have a negative attitude towards banks' advertisements and may not be interested in the emotional appeals embedded therein. For example, an individual who believes that houses should be made socially available by the government may have a negative attitude towards any mortgage advertisements they are exposed to. Apparently, this also resonates with young adults who find it difficult to save enough money to buy their own house. They may see an advertisement for a mortgage and decide to ignore it, based on their understanding of banks not doing enough to help them get on the first rung of the property ladder.

I have this view - you should be able to have social housing, some sort of part buy part you own house for you, there is nothing radical about this banks for you. We have all got to buy into this idea, it's not a fairy tale, we should all be able to afford place to live. This makes me a bit angry, its cosy but in a horrible way, am being construed into owing the bank $£ 200,000$ for the rest of my life. (AC, Female, 30)

Similarly, another issue observed was the ethical stance of individuals regarding how banks operate. In most cases, although they acknowledged that they have to use banks, they stated that they would prefer to use a more ethically appealing bank.

With what the banks have done, mismanaging the money and those unethical things they keep doing, paying themselves huge bonuses, I don't really care about their advertisement, I have the feeling they all wanted our money, am a pensioner, I don't have much to spare, so I stick to one bank and manage my money there, no need to switch around, they are all the same bank and nothing really different (CL, Female, 72). 
I want someone, a bank to speak to me, ethics is quite important here, something to deal with ethics (RC, Female, 32).

Religious affiliation was also found to influence attitude and brand loyalty. Even though the interview guide did not set out to explore this area, two Muslim participants were willing to share their thoughts. They considered interest as unfair and therefore responded negatively to UK bank brands as they were more inclined to use banks that offer Islamic accounts which are Shariah-compliant.

When I came to UK, as a practising Muslim all I was looking for was a bank that can offer me an Amana account which I didn't see on newspaper or billboard advertisement. HSBC is using Amana account which is Muslim sort of banking system where there is no interest. (HA, Male, 37)

Another Muslim participant, though acknowledging the requirements of Islam, mentioned that his perspective is not based on religious requirements.

Well, in a way, it's Islamic, but my perspective is not from the Islamic point of view, my perspective is you are getting something for free; you should get money for what you do. To get my own house, I will save up without having interest. (EG, Male, 24)

For those relocating to the UK, their pre-existing knowledge about global financial brands also influenced their attitudes towards the brand. There was evidence of brand loyalty, particularly looking for banks they know despite seeing advertisements from other brands. They appeared more interested as they wanted to associate with the brand, as they saw it before coming to the UK. There was no evidence of a negative attitude, only willingness to do business with the bank.

When Barclays was in Nigeria, my dad was with them and there was time in the $80 \mathrm{~s}$ when he was in UK, he opened an account with Barclays so we have always grown up with Barclays in our house, so I felt it's more of a family thing. My dad liked Barclays so I thought why not. (JS, Male, 35)

$H S B C$ in China have high requirement if you want to have a current bank account and seeing same HSBC in UK, I was pleased and wanted to open an account. (SW, Female, 24) 


\subsubsection{Expressing the attitude}

Irrespective of factors that might have influenced their attitude, participants were able to express their attitude towards the UK brands after being exposed to their print advertisements, especially with regard to the images and copy that were used by the banks to convey the emotional appeals. Participants were able to relate to the images and felt excited about the promise of good customer services from the bank.

This is beautiful, lovely and attractive, the innocent child playing and enjoying herself, now they have actually indicated that they are the number one financial brand, I don't mind opening a savings accounts for my grandchild here, the choice of an image of a child is quite good, it attracts you to the advert and they have added some verifiable fact. I like the advert and may surely consider the bank. I have watched Nationwide from afar, I think they are quite different, ethically, they seem fine and with this advert, I might actually consider them now. (YU, Female, 47)

I like this, the child looks happy so probably the bank will offer something that is very satisfying, the image of this child help me to think like that because she looks happy. (MG, Female, 25)

The NatWest advert is nice, looking homely and welcoming. You feel you are in the good company of the bank, with the mum and daughter, it shows a bit of love you will expect from the bank. (MR, Female, 56)

Despite the creative features in the advertisements, which should arouse a positive emotion, some participants were displeased by the advertisements and confused by the message and felt that it was irrelevant or inappropriate for them. The lack of trust in banks appeared to be the main hindrance in ensuring a positive attitude towards the advertisement and the brand. Trust in the bank brands formed a core of the customers' attitudes, and while engaging with the advertisements, they considered whether they could trust the claims of the banks, especially whether the bank can meet their expectations. They acknowledged the text and images as they transferred the emotional appeals, but they could not simply believe what the banks were saying in the advertisements. This can be tied to the financial crisis, bad experiences with the banks and media coverage, which influenced participants' attitudes towards bank brands and inadvertently influenced their attitudes towards the advertisements. 
My dream is different and this doesn't come across to me, people don't trust banks now, they are not ethical, they you use our money to do whatever they want. (AC, Female, 30)

Well, they are trying to convince you that they are the number one financial brands by using the picture of a girl smiling but to me, that doesn't attracts me, to me it's just a picture, this doesn't make me trust them still. I don't trust banks at all. (EG, Male, 24)

I don't really trust the advert, maybe that's a general thing, am not so sure how much I trust advertisement in general, with regards to the banks, with the credit crunch, doing something enormous which is a global damage, bleeding countries of their money and get cuts from welfare which would have being used and if they have being responsible and caring like their adverts, maybe that wouldn't have been a problem. (JY, Female, 25)

In addition to the evidence that customers have not been able to trust the banks fully to meet their expectations, participants were of the opinion that banks cannot be their friends and should not present themselves in this way. They wanted banks to provide a good service instead of trying to be friendly, suggesting the need to consider the kind of emotional appeal to embed in a bank advertisement, and there were no indications of any brand affiliation; participants did not feel drawn to use a particular bank brand or feel good about being associated with the bank.

With this playfulness in their advertisements, you expect me to treat my bank as a friend? No, I don't, they are enemies you can't avoid, you just have to use them as there are no alternative. (CB, Male, 20)

I think banks should not portray themselves as friends in their advertisements unless they do actually mean it and be more responsible in the way they spend money and lend people money (TA, Female, 28)

I can see they are trying to show they are somehow caring and some kind of family scene on the front, I don't really trust them, there are enormous cooperation which has potentially do a lot of damage and when they tell you we are friendly, we are going to look after you. (TD, Male, 45)

There was a general lacklustre attitude towards the brand. Even though participants acknowledged how important the banks are, it that appeared that participants were not really concerned about their choice of bank. There was no sense of pride in their choice as they revealed that they have different accounts for different purposes, and in some cases, there was 
no sense of loyalty as they can switch their bank accounts from one bank to another. This did not seem popular with the older adults, however, who had been using the same account for over 20 years.

I am quite comfortable with Barclays, they have offered me good services over the years, I can get a loan for whatever I want and I don't really want to explore another bank. (JA, Female, 62)

I have switched my bank from Santander to Halifax to get their money and now even to First Direct, I do my banking online, I cannot be bothered to stay forever with a bank. (EM, Male, 26)

My present bank is not offering me anything special and I have been seeing offers to switch, I am really planning to do so, I just need to take me my time, this bank might not even miss me. (SH, Female, 32)

Overall, the attitude towards the UK bank brands was not very negative. It appeared that the consumers have recovered from the effects of the financial crisis and are looking forward to more competitive products and customer service, a bank that will offer something different which will appeal to the consumers.

\section{Discussion}

The study sought to extend understanding of the attitude towards UK retail bank brands' advertising strategies and how they influence consumers' attitudes towards their brands. It makes an important contribution by adopting a qualitative research approach to explore in particular emotional appeals in financial services advertisements, which are often considered only utilitarian.

Two studies were carried out to determine what the banks are communicating and how these communications influence the consumers' attitudes towards the brand. The content analysis in Study 1 provided empirical findings which showed that emotional appeals are used for advertising services in the UK. The choices of images and colours are creative decisions made by the advertisers to make the advertisements more appealing. This was found to be 
effective, as participants in Study 2 were able to engage with these creative features and report their attitudes towards the advertisement and the brand.

The theoretical framework for the research highlighted the conscious creative decisions of the brands to embed their advertisements with emotional appeals and encourage a positive attitude towards their brands. The messages presented in the advertisements shown to the participants were considered meaningful and significant to them as customers, who acknowledged the meanings embedded in the advertisements and received the message intended by the banks, so they were closer to making a decision to bank with a particular bank.

Social judgement theory has also be used in a branding and advertisement context to offer insight into how an individual's ideologies and affiliations shape attitudes towards UK retail bank brands: in some cases for individuals who hold banking ethics highly, the marketing communication fell within the latitude of rejection as it did not match their position and expectations, while in other cases, the images used in the advertisement made the messages fall within the latitude of acceptance, when closely matching the individual's position, which therefore leads to an assimilation effect (Meyers-Levy and Sternthal, 1993).

Despite the embedded emotional appeals in the advertisements, persuasion occurs on an individual basis, which is often shaped by different factors as individuals explore the message within their frame of understanding and beliefs; however, this does not remove the importance of images and text which are generally acceptable as appealing, such as a mother hugging her daughter or a child playing by the seaside. These findings provide further evidence that creative features embedded in an advertisement are known to enhance a positive attitude towards the advertisements, which in turn leads to a positive attitude towards the brand (Mitchell and Olson, 1981; Lutz et al., 1983). 
While previous research has focused quantitatively on attitudes towards advertisements and brands, the contribution made by this paper is to explore customers' individual perceptions and ideologies qualitatively, as these influence their attitudes towards bank brands. We were able to identify a relationship and an association between emotional appeals in advertisements which enhance the attitude towards the advertisement and the brand; this offers implications which influence how best to reach out to prospective customers.

The qualitative results helped in developing a better understanding of the thought process between exposure to advertisements and the formation of attitudes, which is personal and individualistic and beneficial in developing a better understanding of attitudes towards brands and advertisements. Our findings also indicated some distinct factors that serve as filters in consumers' minds when exposed to a financial services advertisement - political and religious affiliations and previous brand knowledge in their home country. This presents opportunities for brands to target individuals based on these ideologies.

Consumers' attitudes towards these brands are considered worthy of research as they can predict their purchase intention and behaviour (Bagozzi et al., 1979, p.88; Liu et al., 2012, p.998), which, in turn, affect brand loyalty. Though attitude can be considered relative, it is the overall evaluation of how the brands are meeting the customers' needs, and it highlights the challenges for managers regarding how they can improve their reputation by offering valuable and customer-focused services.

The study has made theoretical and managerial contributions by focusing on the UK banking context, which is an under-researched market that is a crucial player in the financial services market globally. Moreover, the study explored creative features in the advertisements, and emotional appeals presented in the advertisements were explored to understand how 
consumers react to bank advertisements and whether the embedded meanings in the advertisements are transferred.

The findings from this study support previous findings that an emotional attachment is often considered to enhance attitudinal loyalty to the brand and is considered to be a progression beyond a positive attitude (Patwardhan and Balasubramanian, 2011). In most cases, when participants can relate to the advertisements, they develop an emotional connection with the advertisements, so they want to engage and see what the bank has to offer that is different from others.

Furthermore, our qualitative findings support the bi-dimensional nature of feelings towards the advertisements and how it relates to the brand (Brown et al., 1998; Ito and Cacioppo, 2001; Spears and Singh, 2004). The positive and negative feelings towards the advertisements constitute separate constructs; even though participants were exposed to the same advertisements, some displayed a negative attitude towards the advertisements which influences their attitudes towards the brands, while others displayed a positive attitude towards the advertisements and a positive attitude towards the brands. This illustrates the relationship between the emotional reaction towards the advertisements customers are exposed to and their attitudes towards the brands.

The present research has highlighted the possibilities of adopting a semi-structured interview to gain a better understanding of emotional appeals and their relevance to advertisement effectiveness, as it permits some in-depth exploration of consumers' emotional responses to these advertisements (Brodericki et al., 2003). The research put into practice the suggestion by Zinchiak (2014) regarding adopting both quantitative and qualitative methods in marketing research and providing reasons not to ignore the qualitative component in the research plan. 
Some of the main outcomes of a positive attitude towards bank brands are opening more accounts, obtaining more financial products or perhaps switching to a new bank. From the findings, there are indications that consumers are aware of the possibilities of switching to a brand they may consider to offer a better deal; however, the desire to switch seems not to be there, highlighting the challenge for the banks to make switching appealing. As noted by Stewart (1998), who suggested that the reasons for the longevity of a relationship between banks and their customers are ignorance, inertia and dependence, customers feel indifferent towards the bank brands, as it appeared that they are not interested or might not be willing to take action even when they acknowledge that they are not receiving a good service. This lacklustre attitude offers the brands an opportunity to present values and give reasons to consumers.

Four main managerial implications are provided in this study. Firstly, there is a need for managers to present distinct values about their brands to the target audience through their marketing communications. Mann and Kaur (2013) corroborate this as they suggest that selecting an appropriate branding strategy is key in enhancing the equity of a brand as it would support the desired positioning and thus influence consumers' intention to bank. In developing their strategies, retail bank brands need to provide reasons why customers should decide to switch to and/or bank with them, highlighting that special thing about their brands which sets them apart from other brands, as customers look for reasons to switch. In addition to offering this information, banks should not only offer a monetary reward for switching, but also present values that will convince the customers to stay.

Secondly, as trust is considered fundamental to trade and development in the financial sector (Gillespie and Hurley, 2013), managers will have to work continually to regain the trust lost. The customers want to believe that what they see in the advertisements is what they will get from the banks. Customers do not want to be spoon-fed trust; instead, they want to develop 
the trust themselves. Therefore, it is important that managers offer information that allows trust to be built over time, for example, a subtle presentation of ratings, recent awards, industry recognitions and verifiable facts, complementing this information with the services and experience of the banking hall.

Thirdly, managers should endeavour to build relationships with existing customers due to the importance of word-of-mouth testimony. It is also important for managers to consider how they reward customer loyalty. Customers remain with banks as they have been with them since they were young or they are anticipating a better deal. Customers consider how well they are treated, and if the treatment they receive is not good enough, they can be motivated to switch to another bank and may even get paid for doing so.

Finally, Bravo et al. (2012) explain how the corporate brand image of financial institutions is developed, and we propose that there is a need for banks to engage in and highlight charitable activities and any corporate social responsibility, which presents their social or environmental benefits to their community. Lloyds Bank is in partnership with BBC Children in Need and Barclays Digital Eagles hold Tea and Teach sessions across the UK, teaching how to use computers and the Internet. This can help to improve the consumers' attitudes towards the brands as they often consider bank brands greedy and selfish.

\section{Conclusion}

The study presents the result of the content analysis of UK banks' print advertisements, which indicates that emotional appeals are incorporated into their advertisement strategies; these emotional appeals are acknowledged by the customers and the embedded meanings are transferred, which influences their attitudes towards the bank brands. 
The present study contributes to an ongoing trend in research on understanding consumers' attitudes towards bank brands and their advertising strategies as they rebuild the trust and their reputations. It offers theoretical and marketing practice implications for academics, advertisers, brand managers and social media marketing practitioners. As the intensity and frequency of communication have been found to increase mutual trust, helping to solve disputes and misunderstandings (Smith and Barclay, 1997; Mukherjee and Nath, 2003), this study highlights the importance of trust in building a relationship with consumers, suggesting multi-strand trust development strategies which should be complemented with marketing communication strategies.

The fact that this study is based on real-life advertisements and real-life responses from social media network users can be considered as one of its strengths; nonetheless, several limitations must be addressed. The research is exploratory in nature and intended to suggest more research into attitudes towards service brands. The limitations and potential bias in the self-selected interviewees are also acknowledged.

The number of advertisements shown to the participants and the bias are acknowledged and considered limitations of this study. We also recognise that the convenience sample may create issues with generalisability and therefore may not be representative of the population, and our findings may be suggestive rather than conclusive. The study examined attitudes towards the banking industry in a single country. Future research should explore bank brands in other countries and use different media, as the disparate media landscapes in these countries may provide different insights.

\section{References}

Adir, V., Adir, G. and Pascu, N.E. (2012), "Graphic Advertising, as A Specialized Tool of Communication", Procedia-Social and Behavioral Sciences, Vol. 51, pp. 645-649. 
Bagozzi, R.P., Tybout, A.M., Craig, C.S. AND Sternthal, B. (1979), "The construct validity of the tripartite classification of attitudes", Journal of Marketing Research, Vol. , pp. 88-95.

Baines, P., Fill, C. and Page, K. (2008), Marketing, Oxford University Press, Oxford, England.

Barber, L. (2014), "Can Banking Clean Up its Act?" Vital speeches of the day, Vol. 80 No 7, pp. 243-246.

Batra, R. and Ray, M.L. (1986), "Affective responses mediating acceptance of advertising", Journal of Consumer Research, Vol. 13 No. 2, pp. 234-249.

Belch, G.E. and Belch, M.A. (2013), "A content analysis study of the use of celebrity endorsers in magazine advertising", International Journal of Advertising, Vol. 32 No. 3, pp. 369-389

Belch, G.E. \& Belch, M.A. (2014), Advertising and Promotion: An Integrated Marketing Communications Perspective, 10th edn., McGraw-Hill, New York.

Bennett, R. and Kottasz, R. (2012), "Public attitudes towards the UK banking industry following the global financial crisis", International Journal of Bank Marketing, Vol. 30 No. 2, pp. 128-147.

Bovee, C. and Arens, W.F. (2000), Contemporary Advertising. 4th edn., Irwin, Homewood, IL.

Brader, T. (2006), Campaigning for hearts and minds: How emotional appeals in political ads work, University of Chicago Press, Chicago 
Bravo, R., Montaner, T. and Pina, J.M. (2012), "Corporate brand image of financial institutions: a consumer approach", Journal of Product \& Brand Management, Vol. 21 No. 4, pp. 232-245.

Broderick, A., Jogi, A. and Garry, T. (2003), "Tickled Pink: The Personal Meaning of Cause Related Marketing for Customers", Journal of Marketing Management, Vol. 19 No. 5, pp. 583-610.

Brown, S.P., Homer, P.M. and Inman, J.J. (1998), "A meta-analysis of relationships between ad-evoked feelings and advertising responses", Journal of Marketing Research, Vol. , pp. 114-126.

Bryman, A. and Bell, E. (2015), Business Research Methods, Oxford University Press, Oxford, England.

Cacioppo, J.T. and Petty, R.E. (1989), "The elaboration likelihood model: The role of affect and affect-laden information processing in persuasion", in Cafferata, P. and Tybout, A. (Ed.), Cognitive and Affective Responses to Advertising, Lexington Books, Toronto, pp. 69-89.

Clow, K.E., Berry, C.T., Kranenburg, K.E. and James, K.E. (2005), "An Examination of the Visual Element of Service Advertisements", Marketing Management Journal, Vol. 15 No. 1, pp. $33-45$

Cooper, P. (1999), "Consumer understanding, change and qualitative research", International Journal of Market Research, Vol. 41 No. 1, pp. 1-9

Crouch, M. AND Mckenzie, H. (2006), "The logic of small samples in interview-based qualitative research", Social Science Information, Vol. 45 No. 4, pp. 483-499. 
Crowley, K. (2010), "Banks' reputation declined last year, Edelman survey shows", Bloomberg Business Week, Vol. 26. pp. 3

Decrop, A. (2007), "The influence of message format on the effectiveness of print advertisements for tourism destinations", International Journal of Advertising, Vol. 26 No. 4, pp. 505-525.

Denning, S. (2013). Five Steps That Banks Must Take To Achieve The Good Society. [online] Forbes.com. Available at: https://www.forbes.com/sites/stevedenning/2013/02/14/five-steps-that-banks-must-take-toachieve-the-good-society/\#36b56bf114ca [Accessed 10 Mar. 2017].

Eagly, A. H., \& Chaiken, S. (1993), The Psychology of Attitudes, Harcourt Brace Jovanovich, Fort Worth, TX.

Evans, R. (2012). Can we trust the banks to look after our money?. [online] Telegraph.co.uk. Available $\quad$ at: $\quad$ http://www.telegraph.co.uk/finance/personalfinance/bankaccounts/9365003/Can-we-trust-the-banks-to-look-after-our-money.html [Accessed 10 Mar. 2017].

Fowles, J. (1998), "Advertising's fifteen basic appeals", in Petracca, M. and Sorapure, M. (Ed.), Culture: Reading and Writing About American Popular Culture, Prentice Hall, Upper Saddle River, pp. 73-76.

Franke, G.R., Huhmann, B.A. and Phelps, J. (1999), "Appeals in Korean magazine advertising: a content analysis and cross-cultural comparison", Asia Pacific Journal of Management, Vol. 16 No. 2, pp. 249-258.

Ghodeswar, B.M. (2008), "Building brand identity in competitive markets: a conceptual model", Journal of Product \& Brand Management, Vol. 17 No. 1, pp. pp. 4-12. 
Gillespie, N. and Hurley, R. (2013), "Trust and the global financial crisis", in Bachmann, R. And Zahee, A. (Ed.), Advances in Trust Research, Edward Elgar, Chichester, pp. 177-204.

Gritten, A. (2011), "New insights into consumer confidence in financial services", International Journal of Bank Marketing, Vol. 29 No. 2, pp. 90-106.

Hartmann, P., Apaolaza I. V. and Forcada Sainz, F.J. (2005), "Green branding effects on attitude: functional versus emotional positioning strategies", Marketing Intelligence \& Planning, Vol. 23 No. 1, pp. 9-29.

Heath, R., Brandt, D. and Nairn, A. (2006), "Brand Relationships: Strengthened by Emotion, Weakened by Attention", Journal of Advertising Research, Vol. 46 No. 4, pp. 410-419.

Heath, R. (2009), "Emotional engagement: How television builds big brands at low attention", Journal of Advertising Research, Vol. 49 No. 1, pp. 62-73.

Heinonen, K. (2014), "Multiple perspectives on customer relationships", International Journal of Bank Marketing, Vol. 32 No. 6, pp. 450-456.

Hetsroni, A. (2000), "The relationship between values and appeals in Israeli advertising: a smallest space analysis", Journal of Advertising, Vol. 29 No. 3, pp. 55-68

Holbrook, M.B. (1987), "Mirror, mirror, on the wall, what's unfair in the reflections on advertising?", The Journal of Marketing, Vol. 51 No. 3, pp. 95-103.

Holbrook, M.B. and O'Shaughnessy, J. (1984), "The role of emotion in advertising", Psychology \& Marketing, Vol. 1 No. 2, pp. 45-64.

Järvinen, R.A. (2014), "Consumer trust in banking relationships in Europe", International Journal of Bank Marketing, Vol. 32 No. 6, pp. 551-566. 
Johnson, D.S. and Peterson, M. (2014), "Consumer financial anxiety: US regional financial service firms' trust building response to the financial crisis", International Journal of Bank Marketing, Vol. 32 No. 6, pp. 515-533.

Jones, J.P. (1990), "Advertising: Strong Force or Weak Force? Two views an Ocean Apart", International Journal of Advertising, Vol. 9 No. 3, pp. 233-246

Kenning, P. and Plassmann, H. (2005), "NeuroEconomics: An overview from an economic perspective", Brain Research Bulletin, Vol. 67 No. 5, pp. 343-354.

Kinnear, T. C., Kenneth L. Bernhardt and Kathleen H. K. (1995), Principles of Marketing. Harper Collins Publishers. New York.

Kisielius, J. (1982), "The role of memory in understanding advertising media effectiveness: The effect of imagery on consumer decision making", Advances in Consumer Research, Vol. 9 No. 1, pp. 183-186.

Kotler, P. (2000), Marketing management: The millennium edition, Prentice Hall, New Jersey.

Krippendorff, K. (1980), Content Analysis: An Introduction to Its Methodology, Sage, Newbury Park, CA.

Lincoln, Y.S. and Guba, E.G. (1985), Naturalistic Inquiry, Sage, Beverly Hills, CA.

Liu, F., Li, J., Mizerski, D. \& Soh, H. (2012), " 'Self-congruity, brand attitude, and brand loyalty: a study on luxury brands'", European Journal of Marketing, Vol. 46 No. 7/8, pp. $922-937$. 
Lutz, R.J., Mackenzie, S.B. AND Belch, G.E. (1983), Attitude toward the ad as a mediator of advertising effectiveness: Determinants and consequences. Vol. 10, Advances in Consumer Research, Duluth, MN.

Mackenzie, S.B. and Lutz, R.J. (1989), "An empirical examination of the structural antecedents of attitude toward the ad in an advertising pretesting context", The Journal of Marketing, Vol. 53 No. 2, pp. 48-65

Mackenzie, S.B., Lutz, R.J. and Belch, G.E. (1986), "The role of attitude toward the ad as a mediator of advertising effectiveness: A test of competing explanations", Journal of Marketing Research, Vol. 23 No. 2, pp. 130-143.

Mann, B. and Kaur, M. (2013), "Exploring branding strategies of FMCG, services and durables brands: evidence from India", Journal of Product \& Brand Management, Vol. 22 No. 1, pp. 6-17.

Marketline, (2014). Banks Industry Profile: United Kingdom. London: MarketLine Research.

Meyers-Levy, J. and Sternthal, B. (1993), "A two-factor explanation of assimilation and contrast effects", Journal of Marketing Research, Vol. 30 No. 3, pp. 359-368.

Mckechnie, S. (2011), "Consumer confidence in financial services after the crunch: new theories and insights", International Journal of Bank Marketing, Vol. 29 No. 2, pp. 90-106.

Mitchell, A. and Olson, J. (1981), "Are product attribute beliefs characteristics associated with purchasing involvement", The Journal of Marketing, Vol. 49 No. 1, pp. 72-82.

Mitchell, A.A. (1986), "The effect of verbal and visual components of advertisements on brand attitudes and attitude toward the advertisement", Journal of Consumer Research, Vol. 13 No. 1, pp. 12-24. 
Mogaji, E., Farinloye, T. and Aririguzoh, S. (2016), "Factors shaping attitudes towards UK bank brands: An exploratory analysis of social media data", Cogent Business \& Management, Vol. 3 No. 1, pp. 1223389.

Mogaji, E., (2016a). This advert makes me cry: Disclosure of emotional response to advertisement on Facebook. Cogent Business \& Management, Vol. 3 No. 1, pp. 1177906.

Mogaji, E. (2016b). Emotional Appeals in UK Banks' Print Advertisement. Unpublished PhD. University of Bedfordshire.

Mogaji, E. (2015), "Reflecting a diversified country: a content analysis of newspaper advertisements in Great Britain", Marketing Intelligence \& Planning, Vol. 33 No. 6, pp. 908 926.

Moriarty, S.E. (1991), Creative Advertising Theory and Practice. 2nd edn., Prentice-Hall, Englewood Cliffs, N.J.

Mukherjee, A. and NATH, P. (2003), "A model of trust in online relationship banking", International Journal of Bank Marketing, Vol. 21 No. 1, pp. 5-15.

Muzafer S. and Carl I. H. (1961), Social Judgment: Assimilation and Contrast Effects in Communication and Attitude Change, Yale University Press, New Haven, CT.

Neuendorf, K.A. (2002), The Content Analysis Guidebook, Sage, Thousand Oaks, CA.

O'Guinn, T., Allen, C AND Semenik, R. (2006), Advertisng and Integrated Brand Promotion. 4th edn. Mason, Thomson South-Western, OH.

O'Cass, A. and Grace, D. (2004), "Exploring consumer experiences with a service brand", Journal of Product \& Brand Management, Vol. 13 No. 4, pp. 257-268. 
Panda, T.K., Panda, T.K. and Mishra, K. (2013), "Does Emotional Appeal Work in Advertising? The Rationality Behind Using Emotional Appeal to Create Favorable Brand Attitude", IUP Journal of Brand Management, Vol. 10 No. 2, pp. 7-23.

Patwardhan, H. and Balasubramanian, S.K. (2011), "Brand romance: a complementary approach to explain emotional attachment toward brands", Journal of Product \& Brand Management, Vol. 20 No. 4, pp. 297-308.

Pollay, R.W. (1983), "Measuring the cultural values manifest in advertising", Current Issues and Research in Advertising, Vol. 6 No. 1, pp. 71-92.

Saiz, B. and Pilorge, P. (2010). Understanding Customer Behaviour in Retail Banking: The impact of the Credit Crisis across Europe. Ernst \& Young: London.

Salander, B. (2010). Emotionality in Business-to-business Marketing communications. Unpublished PhD. University of Northumbria at Newcastle.

Saunders, M., Lewis, P. and Thornhill, A. (2015), Research Methods for Business Students. 7th edn., Pearson Education, England.

Shenton, A.K. (2004), "Strategies for ensuring trustworthiness in qualitative research projects", Education for Information, Vol. 22 No. 2, pp. 63-75.

Shimp, T.A. (1993. Promotion Management and Marketing Communications. 3rd edn., Harcourt Brace Jovanovich, Orlando.

Smith, J.B. and Barclay, D.W. (1997), "The effects of organizational differences and trust on the effectiveness of selling partner relationships", The Journal of Marketing, Vol. 61 No. 1, pp. 3-21. 
Hogg, M., Askegaard, S., Bamossy, G. and Solomon, M. (2006), Consumer behaviour: a European perspective. 6th edn., Pearson Education, Upper Saddle River, NJ.

Spears, N. and Singh, S.N. (2004), "Measuring attitude toward the brand and purchase intentions", Journal of Current Issues \& Research in Advertising, Vol. 26 No. 2, pp. 53-66.

Starch, D., 1966. Measuring Advertising Readership and Results, McGraw-Hill, New York, NY.

Stewart, K. (1998), "An exploration of customer exit in retail banking", International Journal of Bank Marketing, Vol. 16 No. 1, pp. 6-14.

Strauss, A. and Corbin, J. (1994), "Grounded theory methodology: An overview", in Denzin, N.K and Lincoln, Y. S. (Eds.), Handbook of Qualitative Research, Sage, Thousand Oaks, CA, pp. 273-285.

Strauss, A.L. and Corbin, J.M. (1990), Basics of Qualitative Research, Sage, Newbury Park, CA.

Unnava, H.R. and Burnkrant, R.E. (1991), "An imagery-processing view of the role of pictures in print advertisements", Journal of Marketing Research, Vol. 28 No. 2, pp. 226-231.

Wray, R. (2008), "The big deals that shredded fortunes and reputations", The Guardian,31 December, p.13.

Wilmshurst, J. and Mackay, A. (2010), Fundamentals of Advertising. 2nd edn., Routledge, London and New York.

Yu, L. (2007), "Relating the Visual and the Headline in Chinese Print Advertisements", Visible Language, Vol. 41 No. 2, pp. 163. 
Zinchiak, M. (2014). Marrying Qualitative with Quantitative Market Research. [online]

Ama.org. Available at:

https://www.ama.org/publications/eNewsletters/MarketingInsightsNewsletter/Pages/marrying -qualitative-with-quantitative-market-research.aspx [Accessed 10 Mar. 2017].

\begin{abstract}
About the authors
Emmanuel Mogaji, Ph.D. is a researcher at the Business and Management Research Institute of University of Bedfordshire Business School. Emmanuel's primary areas of interest are ABCDE of Marketing Communications - Advertising | Branding | Communications | Digital | Ethics. He has published peer-reviewed journal articles and book chapters, and presented his works in a large number of national and international conferences. He has previously worked as a marketing communication executive, responsible for creative designs and management of marketing campaigns, liaising and building relationships with a range of stakeholders.
\end{abstract}

Annie Danbury is a Senior Lecturer in Marketing at the University of Bedfordshire, UK, where she has developed, taught and managed marketing communications courses at mainly postgraduate level for over ten years. Her research specialism includes the impact of involvement on advertising processing. Additional research interests include brand advocacy and how to create a trustworthy brand image through brand communication. Dr. Danbury is a Fellow of the Higher Education Academy and Associate Member of the Chartered Institute of Marketing in the UK and a regular reviewer for several international marketing journals. 